\title{
Going Up or Getting Out? Professional insecurity and austerity in the South African health sector
}

Elizabeth Hull, SOAS University of London

\author{
$<$ ABS $>$ Abstract \\ As a precondition of belonging, professionalism is often a taken-for-granted feature of being \\ middle class. Yet ethnographic attention to experiences of work reveals that professional \\ identity can be fragile. Drawing on ethnographic research among nurses in KwaZulu-Natal, \\ this article traces the feelings of precarity about work and the ambivalence that pervades \\ ideas of professionalism. This ambiguity arises partly out of a peculiarly South African story \\ in which histories of professionalism are entwined with the repressive apartheid project of \\ separate development. Many of the professionals working as teachers, nurses, lawyers and \\ administrators today were trained in the former 'homelands'. Practices of professionalism are \\ entangled with those of clientelism inherited from this earlier period of homeland politics. \\ These local histories combine with wider processes of neoliberalism, as conditions of \\ austerity produce structural shifts towards casualization. The article traces these dynamics in \\ the stories of two nurses and considers what may be at stake politically as middle-class \\ trajectories are threatened. Moving away from a view of the middle classes as either \\ democratic or anti-democratic, feelings of ambivalence about work make questions of \\ political allegiance an ambiguous and fraught matter.
}

\section{$<$ ABS $>$ Résumé}

En tant que précondition d'appartenance, le professionnalisme est souvent une caractéristique considérée comme allant de soi pour décrire ce qu'est être de classe moyenne. Pourtant, l'attention ethnographique aux expériences de travail révèle que l'identité professionnelle peut être fragile. S'appuyant sur des études ethnographiques menées auprès d'infirmières au KwaZulu-Natal, cet article décrit les sentiments de précarité concernant le travail et l'ambivalence qui imprègne les idées de professionnalisme. Cette ambiguïté résulte en partie d'une histoire spécifiquement sud-africaine dans laquelle les histoires de professionnalisme sont intimement liées au projet de développement séparé du régime d'apartheid répressif. Parmi les professionnels qui travaillent aujourd'hui comme enseignants, infirmiers, juristes et 
administrateurs, beaucoup ont été formés dans les anciens « homelands » (foyers nationaux). Les pratiques du professionnalisme sont indissociables de celles du clientélisme hérité de cette période de politique des homelands. Ces histoires locales s'associent à des processus de néolibéralisme plus larges, des conditions d'austérité produisant des changements structurels vers la précarisation. L'article décrit ces dynamiques dans les histoires de deux infirmières et examine les enjeux politiques possibles à l'heure où les trajectoires des classes moyennes sont menacées. Loin d'une vision des classes moyennes qui serait démocratique ou antidémocratique, les sentiments d'ambivalence autour du travail font des questions d'allégeance politique un sujet ambigu et délicat. 
$<$ LRH $>$ Elizabeth Hull

$<$ RRH $>$ Health work and insecurity in South Africa

$<$ AT $>$ Going up or getting out? Professional insecurity, ambivalence and austerity in the South African health sector

$<\mathrm{AU}>$ Elizabeth Hull

$<\mathbf{A F}>$ Elizabeth Hull is Senior Lecturer in Anthropology at SOAS University of London. Her book Contingent Citizens: professional aspiration in a South African hospital was published in 2017 by Bloomsbury. Email: e.hull@soas.ac.uk

\section{$<$ A $>$ Introduction}

Global debates have highlighted the growing visibility of the middle classes in many African countries, fuelling narratives of 'Africa rising'. Lavish consumption habits mark the distinctiveness of the 'new' middle classes, they suggest. ${ }^{1}$ In contrast, occupational identity is often treated merely as a proxy for class status, taken as a prerequisite of middle-class belonging. However, in contexts of austerity where jobs are insecure and middle-class lifestyles are funded riskily on borrowed credit (James 2015), a focus on experiences of work reveals a great deal of ambivalence about the prospects of class mobility. ${ }^{2}$ In South Africa, where the legitimacy of the ruling African National Congress (ANC) depends on the support of a large (albeit heterogeneous) middle-class constituency, the political stakes of this uncertainty may be high.

Since the beginning of liberal democracy in 1994, the growth of a black middle class has been aided by a host of policies aimed at promoting economic success among the black majority who were previously marginalized by the apartheid regime. ${ }^{3}$ But as attention turns to this group, disagreements emerge about who exactly belongs to the middle class, and how to understand its position vis-à-vis the state, market and society. These discussions share much in common with debates about the middle classes globally. Political commentaries represent the middle classes either as strengthening civil society by developing distrust in the 
state and fostering healthy democratic debate, or else reproducing the status quo as beneficiaries of elite political systems (Lentz 2020).

Ethnographic examples from around the world, however, call into question the dichotomous view of the middle classes as either democratic or anti-democratic. In India, the emergence of a 'new' middle class has entailed a shift from earlier values associated with the statemanaged economy to identities increasingly marked by consumerism (Fernandes 2006). The preoccupation with consumption is associated with a middle-class retreat from ethical and political responsibility towards nation building. Yet Lila Fernandes argues that internal differentiation within the middle classes, as well as contestations over policies of economic reform, call into question claims that they are simply the beneficiaries of liberalization. She suggests that analysis of the middle classes should move beyond the existing focus on electoral politics to explore national political cultures of belonging and aspiration as they are enacted in everyday life. In a similar vein, an ethnography by Samuli Schielke (2015) demonstrates how Islamist politics and democratic values are not irreducibly different options for the middle classes in Egypt. Instead, moral and spiritual lived experiences produce multiple ambiguities. He argues that sheer uncertainty about the future prohibits clear-cut political commitments. In South Africa's neighbouring Mozambique, the middle class is produced by relationships of dependency on the ruling party elite. However, tensions are growing as these relationships become increasingly unreliable sources of wealth and security (Sumich 2018). Uniting these examples is the sense of ambivalence that pervades middleclass experience.

In South Africa, these ambiguities find expression in narratives and experiences of employment. While black people depended on wage labour during the apartheid years, the exploitative and discriminatory nature of this employment precluded a life of dignity and security. Racialized exclusion from professional work was a hallmark of apartheid-era social engineering, albeit with certain carefully prescribed exceptions, especially in the homelands and in occupations such as nursing when the demand for healthcare necessitated them. Consequently, being fully a citizen in post-apartheid South Africa became synonymous with access to 'free and dignified jobs' (Barchiesi 2011: 3). Yet as I will show for nurses working in KwaZulu-Natal, experiences of work present challenges to professional identity and consequently to the meanings of belonging and aspiration. The post-apartheid workplace is one in which liberal democratic values, clientelist practices and policies of fiscal austerity 
intersect. The state, the market and patrimonial-style elements of governance are brought into play with one another, producing contradictory outcomes that underpin the ambivalent experiences of those employed in state institutions. During apartheid, the professionalization of Africans often took place in the 'homelands', where racist restrictions on their employment were removed. ${ }^{4}$ Critics often dismissed them as the beneficiaries of the corrupt project of separate development. Today, public administrations are entangled with those of clientelism inherited from this earlier period of homeland politics (Chipkin and Meny-Gibert 2012). Professionals must reckon with this challenging work environment, where class aspiration is often understood as inimical to the aims of service delivery. For instance, a preoccupation with career advancement is prioritized over care (von Holdt 2010) or senior posts are sought along clientelist channels (Chipkin and Meny-Gibert 2012; Hyslop 2005). In this context, professionalism emerges as a fraught and sometimes tenuous value (Hull 2017; Marks 1994).

In recent years, fiscal austerity has forced public institutions to prioritize cost containment above other goals (Powers 2019; Schneider et al. 2007). This has occurred alongside decentralization, placing new demands on local governments tasked with delivering democratic promises in a social landscape marred by inequalities and growing exposure to the global economy.

The aim of this article is to investigate middle-class aspiration through the lens of professionalism. This builds on my previous work focusing on the struggles entailed in producing and maintaining professional identities (Hull 2017). Here, I develop the argument further by drawing on Leo Kuper's attention to ambivalence and workplace struggle (Kuper 1965). I consider this in relation both to the ways in which professionalism is shaped by apartheid-era practices and to recent shifts towards austerity and casualization. How are middle-class trajectories influenced by these economic and institutional shifts? How do competing agendas in the workplace shape expectations, either by fostering feelings of entitlement to government jobs or by encouraging a search for alternatives? Focusing on people's experiences of the public-sector workplace draws attention to the sources of contestation felt by the middle classes over the trajectories of institutions that are charged with the responsibility of democratic renewal, as well as over the limits of their own professional mobility within these institutions. 
I use two examples from my ethnographic research among nurses in KwaZulu-Natal. One account describes a nurse manager with nearly thirty years of professional experience, and the other a trainee nurse about to embark on her career and hopeful of a middle-class life for herself and her children in the future. ${ }^{5}$ In both examples, despite their differing circumstances, the pursuit of economic activities outside the professional structures of formal employment was important for middle-class realization. Ambivalent about the capacity of the public-sector workplace to meet their aspirations, they negotiated the trade-offs between 'going up' the professional ladder and getting out to seek other pursuits. This weakening reliance on the public-sector workplace suggests an unstable relationship between professionals and the ruling party. Through these examples I bring professional identity, livelihoods and questions of political allegiance within a single frame. Doing so provides a deeper understanding of the ways in which class aspirations are formed in relation to the opportunities and limitations of the post-apartheid workplace.

\section{$<\mathrm{A}>$ The middle classes in South Africa: introducing ambivalence}

One of the clearest signs of change since the beginning of South Africa's liberal democracy in 1994 is the growth of the middle classes. This has been attributed both to opportunities created by expanding markets and to the removal of apartheid racial barriers alongside government interventions such as the affirmative action programme, Black Economic Empowerment (Southall 2016). However, the extent of the middle classes' growth has been much debated, particularly given that the term 'middle class' can often be as misleading as it is illuminating. Despite the flashy lifestyles of South Africa's elites often depicted in the media, the economic status of the new middle classes is variable and not always secure, particularly because savings are low and levels of indebtedness very high (Visagie and Posel 2013). ${ }^{6}$

The picture is further complicated by people's diverse, subjective understandings of class position. The 2008-09 documentary Phakathi: Soweto's middle class follows sociologist Mosa Phadi as she interviews residents of South Africa's largest black township about their class identities. Interviewees ranged from an unemployed shack dweller with no electricity or running water to a business owner living in a spacious modern house. Despite their differing circumstances, all identified as middle class, highlighting quite how relative the term can be, as well as the range of possible values and meanings it confers (Phadi and Ceruti 2011).

Others highlight how class identification remains mediated profoundly by race, with well-off, 
black South Africans often viewing themselves only contingently as members of the middle class (Mattes 2015) or identifying first and foremost in racial terms (Ngoma 2016).

In my own research in KwaZulu-Natal, I found that people used the term 'professional' instead of 'middle class' to denote aspirational identity. I therefore use the term 'middle class' in this article not as the self-ascribed term of my interlocutors but rather to position my analysis in relation to debates about class aspiration and belonging. Whereas professionalism is often treated as merely a descriptive identifier in these discussions, I instead approach it as a concept that is contentious and always in the making, emerging through particular historical and institutional processes (Hull 2017).

The debate about the middle classes, both in South Africa and globally, becomes polarized in relation to whether or not its growth holds the possibility of consolidating democratic processes and values. Arguments in favour contend that the middle classes develop a set of values and behaviours that diffuse political tensions and create support for the principles of democracy (Netshitenzhe 2014). The middle classes are likely to be critical of government policy, exposing nepotism and consequently presenting a growing challenge to ANC hegemony (Everatt 2013; 2014). Robert Mattes suggests that there is dwindling support for the ANC among the black middle class, as evidenced either by their opting out of democratic processes such as voting, or by their expression of an intention to support alternative parties (Mattes 2015). In the context of a powerful one-party system, this withdrawal or switching of allegiance carries, for some, the hope of democratic renewal. ${ }^{7}$ Disengagement from ANC-led politics, either by voicing discontent or by opting out, makes the middle classes an unreliable support base for the government.

In another study, Lawrence Schlemmer finds that the black middle classes do hold allegiance to the ANC but he rejects the idea that they are 'an ideological captive of the ANC', arguing instead that they base their allegiance on 'pragmatic choice' (Schlemmer 2005: 11). He therefore concurs with the optimistic view of the middle classes as positively strengthening democratic processes. Echoing the utopian spirit of post-war Western Europe and America, civil society is potentially empowered through the creation of an inclusive and growing middle class.

A contrasting position emphasizes the vested interests of the middle classes in the ANCgoverned status quo, essentially concurring with a theory of middle-class 'capture' of the 
state (Lentz 2016: 37). The democratic transition during the early 1990s is a key moment in this story, which many argued amounted to 'a power grab by a middle class risen from among the recently oppressed' (Saul and Bond 2014: 122). In his wide-ranging study of the 'new black middle class' in the subsequent years, Roger Southall (2016) similarly concludes that the middle classes are the key beneficiaries of the post-apartheid dispensation, albeit to varying degrees depending on their position in the workforce and their particular relationship to the ruling party.

These discussions reveal a contradictory picture. On the one hand, arguments about democratic consolidation - often taking their cue from prominent American theorists (Lipset 1959; Moore 1966) - risk overlooking historically specific patterns of class formation in South Africa. As Southall argues, the middle classes have a deep-seated, instrumental connection to the 'party state', implying that the notion of a civil society occupying a space independent from the state is misleading especially in former colonial contexts. On the other hand, arguments concurring with the view of a middle-class 'capture' of the state have their own limitations. They are generally aligned with the dominant strand of neo-Marxian scholarship, which, having focused predominantly on working-class life and politics since the 1970s, lacks a body of literature addressing the experiences or subjectivities of the middle classes. ${ }^{8}$ The absence of detailed qualitative work on middle-class experience, aspiration and identity in recent decades may partly underpin the polarization of current debates about the role of the middle classes, either as the beneficiaries of the current political status quo or as a potential challenge to it. $^{9}$

Earlier Weberian approaches to the study of class and 'elites' by Leo Kuper and other anthropologists in the 1950s and 1960s are instructive. Rather than treating occupation as a proxy for class or a label that conferred social status, Leo Kuper (1965) paid close attention to the institutional configurations, constraints and dilemmas encountered during work itself. This ethnographic focus on occupational experience revealed multiple articulations of 'ambivalence' and 'ambiguity' among professionals about their positions and their relationships with the institutions that employed them. For while, on the one hand, people sought upward mobility through professionalization, on the other hand they encountered tremendous barriers in a system skewed against them on racial grounds. Not only did this create obstacles to class mobility, it could also produce ethical dilemmas as people struggled to negotiate conflicting values. Such tensions meant that the job was 'beset with ambiguity', 
Kuper argued (ibid.: 253). For instance, conflicts of loyalty played out in daily experiences of work, as clerks came either to participate in the domineering behaviour of their white superiors towards clients, or else to swallow resentment and 'suffer vicariously' (ibid.: 255). Yet while this exposed them to accusations of betrayal and 'selling out', these civil servants could also be viewed with tolerance by fellow educated Africans, especially where help had been elicited (ibid.: 256). Professionals occupied an ambiguous space where identities and allegiances were not clear-cut.

The ambivalent character of professional identity in South Africa is closely linked to the role of the Bantustans in fostering a black professional class (Gibbs 2020; Hull 2017). The middle classes who pursued professional careers inside the Bantustans have long been dismissed as beneficiaries of the corrupt and repressive project of separate development. There is growing recognition, however, that these critiques of homeland policy fail to recognize the role of the Bantustans not only in catalysing political mobilization but also in training and developing many of the professionals working in South Africa's public administrations today (Beinart 2012; Chipkin and Meny-Gibert 2012; Gibbs 2020).

These histories have produced contradictory meanings for professionalism that share similarities with examples from beyond South Africa. Professionalism and politics are interwoven projects. At times, professionals have played the role of mediating between traditional and bureaucratic spheres, articulating and navigating the boundaries between different realms of governance (Fumanti 2003; Jacobson 1973). At other times, professional values of civic duty offer 'alternative forms of identification beyond the ethnic or political' (Hull 2017: 41; cf. Spronk 2012). Professionals traverse the boundaries between specialist and bureaucratic domains, using state-sanctioned systems of education and accreditation to preserve occupational boundaries, while also demanding autonomy from the state (Hull 2017; Marks 1994). They also frequently traverse economic domains, combining their income with farming or other lucrative activities (Berry 1985; James 2015; Kitching 1980; Konings and Ravell 1986; Mabandla 2015). A key challenge for understanding middle-class experience is to trace the ways in which professional identities navigate these social tensions and competing ideologies in the workplace.

In South Africa, the formal racial barriers that defined the context of Kuper's study have given way to new tensions. Amid competing agendas and constraints, middle-class 
allegiances may be pulled in different directions. The following two sections trace these dynamics in the experiences of two nurses.

\section{$<\mathrm{A}>$ Going up or getting out}

Mr Dlamini, a senior nurse manager working in a hospital in northern KwaZulu-Natal, was born in around 1965 in a rural area near to the border between South Africa and Swaziland. ${ }^{10}$ His parents worked as waged farm labourers and owned several cattle. When the area became a white farm settlement, the family was relocated to a village inside the newly formed KwaZulu homeland where he subsequently grew up. ${ }^{11} \mathrm{He}$ described himself as a hardworking and motivated student during his school days. Yet he spoke about being held back by circumstances, for instance because the school he attended lacked teachers with expertise in subjects such as mathematics and physics. At around the age of fifteen, he became the guardian of his three younger siblings after the sudden departure of both parents to the city. Neither returned; he was reunited with his mother only years later. To step into his new role as breadwinner, he took up odd jobs such as building and small repairs, supported by the mentorship of a white 'mission teacher' who arranged jobs for him and several other boys. 'He employed clever boys like us,' he said. 'We were different from the others ... We were really taught how to work for pay.' Leaving school without adequate certification, he described himself as 'lacking direction'. With few other options available to him and urgently needing to support his siblings, he applied for the nurse training course at the nearby nursing college, where students received payment from the beginning of the course. His application was successful and he began training. Subsequently pursuing part of his education in Durban, he returned to the KwaZulu homeland to take up a post in a hospital. In 1997, shortly after the Bantustans had been dismantled, he moved to another nearby hospital where he has worked ever since.

Mr Dlamini's story is one of many examples of public-sector workers who, coming from humble beginnings, managed to forge a professional life partly because of expanding opportunities created within the Bantustans. His account resonated in important ways with interviews I conducted with other male nurses, revealing the interplay of gender and class during this period. While a small number spoke of their motivation to enter nursing as a desire to help people - sometimes accompanied by moving personal stories of hardship and care for sick relatives - it was more typical for male nurses to describe their choice as the outcome of limited options. Such a narrative emerges strongly in Shula Marks' discussion of 
the black male orderlies and nurses who worked in the mines in the 1960s and 1970s. ${ }^{12}$ Female nurses often came from well-educated families and harboured middle-class aspirations, in contrast to the male orderlies who were drawn from the migrant labour force. For the men, nursing was understood to be their best option among limited choices; they 'appreciated that the alternative to the work in the hospital was a return to the highly hazardous and arduous rock-face' (Marks 2002: 188). Marks describes the tensions that arose as the number of female nurses increased. ${ }^{13}$ Due in part to their backgrounds and expectations, the women proved more difficult to discipline than the male orderlies. Running counter to typical gender stereotypes, Marks argues that, due to men's appreciation of their work and the absence of class differentials between them and their patients, many were more committed and caring in their treatment of patients than their female counterparts.

Like the male nurses Marks interviewed, Mr Dlamini spoke with integrity and pride about his work. My ethnographic encounters with him suggested that he resembled a 'reformer', someone committed to an ethic of care and improvement at work, in contrast to a 'conservative', who is 'content with the current situation and the rents they derive from it' (Olivier de Sardan 2014: 426). He frequently sought ways to help patients or resolve problems even when this involved bypassing bureaucratic stipulations or taking responsibility for difficult decisions. Yet he was not without disillusionment and spoke frankly about the problems, as he saw them, of poor communication between management and clinical staff, lack of autonomy, especially for mid-level managers, and a poor work ethic among some of his juniors. Adopting a common-sense discourse about the individual rather than structural causes of workplace dissatisfaction, he would sometimes join with other senior nurses in blaming their junior counterparts for harbouring 'bad attitude' instead of recognizing the ways in which their poorer remuneration and working conditions, and extreme workplace stratification, influenced interpersonal dynamics. ${ }^{14}$ Nonetheless, as a manager, he was liked and respected, with nurses remarking on his polite manner and responsiveness to their needs.

As his account suggests, the emerging middle classes located in the Bantustans were not drawn exclusively from an existing political and educated stratum of 'power elites'. ${ }^{15}$ While a good deal of the government's transfer of funds to the homelands found its way into the pockets of elite politicians, civil servants and businessmen, as well as into the funding of forced relocations and displacements, a significant amount - over 50 per cent in the 1970s went to the funding of public services and agriculture (Beinart 2012: 14). This included a 
sizeable increase of funds to hospitals. These growing bureaucracies and services provided many people with secure employment, creating jobs and training opportunities that, for junior nurses such as Mr Dlamini, were often more advantageous than in the cities. In the Bantustans, unlike in city hospitals, racial barriers to upward mobility were removed in order to foster a black middle class and create legitimacy for apartheid's project of separate development. In hospitals in KwaZulu, restrictions on the employment of African matrons and other senior nursing staff were removed in 1977 and the Nursing Council actively encouraged hospitals to promote African nurses to senior roles (Hull 2009: 66). ${ }^{16}$ Consequently, as Gibbs (2020) explains in relation to lawyers, the Bantustans became places in which professional training, experience and reputation could be fostered in ways that were frequently restricted for Africans in the cities. For good or bad, professional trajectories were inexorably entangled with the project of separate development.

During the country's transition after the beginning of majority rule in 1994 - which included the creation of a unified healthcare system - the Bantustans were dismantled. Yet their modes of operation proved more persistent. As the ANC transformed from an activist organization to a governing party in the early 1990s, it was necessary to consolidate support in areas where the ANC was organizationally weak and lacked a political following. Tom Lodge explains:

$<$ EXT $>$ The quickest way to accomplish such expansion was through the incorporation of the elites and networks consolidated around homeland polities. The corollary to this was that in certain predominantly rural provinces the ANC's local leadership would reenact the social relationships of established patterns of clientelistic politics. (Lodge 2014: 17)

Governance and institutional practice, especially in rural areas, came to operate in quintessentially neo-patrimonial ways, combining bureaucratic elements with clientelist ones.

This raises important questions about the status and meaning of professionalism in South Africa today. Both the historical connection to the discredited Bantustans and this contemporary merging of different modes of governance produce ambiguous associations. On the one hand, professional identity offers an alternative workplace ethic to clientelism operating along political or ethnic lines (Fumanti 2006; Hull 2017: 41; Spronk 2012). On the other, routes to professionalization may unavoidably encounter these networks, producing dilemmas with divergent outcomes. A sense of unease emerged in my interviews with $\mathrm{Mr}$ 
Dlamini. Entering the higher rungs of the profession and becoming a manager was viewed as a crucial personal goal. In part, this had to do with sustaining masculine identity in a predominantly female sphere of work: 'I am a man,' he said. 'I have to go up.' Yet this aspiration was countered by other factors. Discussing his future plans, he explained that, while he would like to consider the role of hospital manager, he was also deterred from doing so. 'I am not political. You have to affiliate to get these higher positions,' he said, referring to ANC membership. Instead, he explained that while he would not give up nursing entirely he felt a moral commitment to continue using his skills - he had also begun to invest his salary in agriculture. He had a plot located near a government-managed irrigation scheme to which he was applying for water. He refused to apply for land on the scheme itself, declaring that he 'must be independent [from the government]'. At the time of the interview, his relatives were clearing the land in preparation for planting.

The transferral of income between activities reflects long-standing middle-class trajectories in the region. In order to overcome the barriers to professional advancement or to consolidate class status, professionals have often combined salaries with other income-creating activities, especially in agriculture. In the early twentieth century, as Nkululeko Mabandla (2015) shows, access to land was a crucial factor in fostering the reproduction of a black middle class in Mthatha in the Eastern Cape. Members of this class reinvested salaries earned in white-collar occupations, generating additional income through farming. This allowed them both to mitigate political and economic risks and to generate income to pay for the education of offspring. The intergenerational transfer of income between formal employment, agriculture and education is common elsewhere in Africa (Berry 1985; Kitching 1980; Konings and Ravell 1986). Deborah James (2015) shows how, in South Africa today, salaries from formal employment enter into complex chains of investments, lending and other practices to further accumulation and pay off debts.

Mr Dlamini's dilemma also reflects particular tensions for professionals working in former homeland settings. While on the one hand he aspires to achieve promotion and professional seniority, on the other his ambivalence about the politicized nature of senior roles encourages him to seek alternatives to public-sector employment. In Mr Dlamini's case, we see various elements in tension: a professional, bureaucratic ethic of public service; an individualist desire for professional achievement; and a partial exit from professional work, partly as a 
strategy of upward mobility by reinvesting a salary productively, and partly in response to conflicted ethics arising at work.

Mr Dlamini's distancing from the ANC - including an expressed intention not to vote in the next election - and a desire for 'independence' from government resemble the findings by Mattes and others: that the middle classes are disengaging from electoral politics (Mattes 2015). ${ }^{17}$ However, his comments also revealed a more ambiguous relationship to the ANC government. This ambivalence arose from attempts to navigate contradictory rationales at work. He rejected the link between upward mobility and party allegiance, instead expressing commitment to ideas of civic duty. Yet the political and the professional were inextricably interwoven in practice. Mr Dlamini's ethic of engagement with workplace debates about public provisioning entailed a continued reliance on government. The ambiguity placed him betwixt and between - a tension hardly resolved by his partial departure from the institution. Reliance on the state was a mixed blessing: necessary yet also limiting.

The tension between government employment and participation in alternative activities is a key issue in a context where skilled work is needed by government and where the workplace has become a site of citizenship making (Barchiesi 2011). While the black middle class has formed predominantly within state institutions, Jason Musyoka argues - in contrast to Southall - that 'a captured state undermines the project of creating a black middle class' (Musyoka 2018). This is because the failure of government to function efficiently and fairly inhibits the middle class's transition 'from direct state employment to being competitive entrepreneurs in the private sector', a transition that was successfully facilitated for white South Africans under apartheid (ibid.).

Musyoka's observation underpins the possible dissatisfactions likely to emerge, a tension evident in Mr Dlamini's account, for whom farming may be one of the only viable alternatives. The example shows how histories of professionalism intersect uncomfortably with contemporary modes of governance, producing feelings of ambivalence towards the government. In the context of a strained healthcare service, such dynamics have implications for nurse retention.

In the next example, a political economy of austerity interacts with personal circumstances beyond work both to produce and to limit middle-class strategies. Ambivalence arises here 
because government employment, albeit in a different way to the example just provided, is necessary yet insufficient to meet aspirations that span across several family members.

\section{$<\mathrm{A}>$ Middle-class aspiration in a time of austerity}

Historically, nursing was considered a relatively elite profession and offered one of the few routes to middle-class status for women in South Africa. Today, with a starting salary of at least 9,000 rand (about US\$600) per month, even those at the lowest end of the nursing hierarchy comfortably meet the criteria for income-based definitions of the middle class. ${ }^{18}$ Despite this, nursing is losing its appeal, failing to attract new students or retain those already trained. In a 2011 Nursing Summit held in Johannesburg to address this mounting crisis, many participants expressed concerns that the status of nursing was being eroded in a process of de-professionalization. Despite calls to 'revitalize' nursing (Mafika 2013), problems of recruitment and retention remain severe. These present major challenges to South Africa's health system, particularly in the wake of plans to roll out a National Health Insurance (NHI) programme (Smith et al. 2018). Intended to widen access to healthcare and reduce inequalities, NHI will also create new demands on key human resources, especially in nursing.

According to Gillian Hart (2014), two contradictory forces characterize South Africa's current political crisis, both of which are apparent in the trajectory of public healthcare provision. 'De-nationalization' entails the financialization of the economy and its shift towards patterns of global neoliberalism, producing inequality and deepening the marginalization of the poor. Casualization in the nursing sector is a clear example of this, to which I turn in this section. Policies of fiscal austerity in alignment with global neoliberal orthodoxies restructure healthcare institutions in line with short-term financial goals and give rise to burgeoning networks of informal labour supply. An opposing force identified by Hart is that of 're-nationalization', evident in discourses about the NHI, which is sometimes evoked as an example of progress towards a 'national democratic revolution', a theory of revolutionary progression from capitalism to socialism involving an initial stage of bourgeois national democracy. ${ }^{19}$ With its roots in the anti-apartheid struggle, the "national democratic revolution' has deep resonance among many South Africans. While many have celebrated these progressive plans, the challenge will lie in their implementation (Marais 2011; Naidoo 2012), which must reckon with the forces of de-nationalization: those of austerity, labour devaluation and casualization. 
These competing agendas expose some of the complexities and contradictions of class formation and middle-class expectations in South Africa today. The public sector has grown and has created employment opportunities for the aspiring middle classes. Yet what type of employment does this entail, and how secure is it? Moreover, given that nursing salaries fall within measurements of middle-class belonging, it is necessary to look at wider family relations, particularly the financial obligations that individuals may have to relatives, to understand why nurses seek work in the informal sector. How do personal circumstances and family pressures create additional strains, altering career strategies? In this section, I draw on the experience of one trainee nurse, illustrating some of the ways in which economic factors - especially processes of casualization - dovetail with individual pressures to create particular outcomes.

I visited a trainee nurse I call Mbali in her home in Umlazi, a large township on the outskirts of Durban. She lived in a small, rented, four-room 'matchbox' house with her two children: a son aged thirteen and a daughter aged nineteen. ${ }^{20}$ Photographs neatly displayed on the cabinet under the television showed portraits of each child in their school uniform, and a school class photo of her son. Three more photographs depicted Mbali as a student nurse: one sitting at a desk surrounded by other students; another in the hospital ward; and the third a portrait of her wearing her nursing uniform. The photographs conveyed the values of hard work and educational achievement that Mbali recognized as necessary to achieving the life she hoped for. Her partner, a policeman, had died five years previously, sadly before the couple was able to marry. With financial help from his family, she was sending her son to a formerly exclusively white, fee-paying school outside the township. This was an example of what Mark Hunter (2017) identifies in a study of schooling practices in the same area. In an effort to achieve upward mobility, families in Umlazi go to considerable effort to send children to these 'outside' schools that carry high status in comparison to schools in the township. Even relatively poor families strategize to send one or more children to such schools, making shortterm sacrifices in the hope of a professional career path for the child.

Despite still being a student herself, Mbali's priority was to help her children financially to pursue professional careers. Her daughter worked in a fast-food outlet and wanted to become a nurse or radiographer. Promising to help her as soon as she was working, for now Mbali asked her daughter to be patient. Mbali was desperate to begin work but had not received her certification yet. She was seeking agency work in order to earn money before getting 
permanent employment. ${ }^{21}$ She told me that nursing agencies employed nurses in an assistanttype role even if they didn't have their results yet. Rather than viewing this decision as a temporary measure before moving on to permanent work in formal employment, she intended to combine agency and formal work for as long as possible, suggesting that casual work may be integrated as part of longer-term career strategies. I understand agency work to be partially 'informal' because there is no formal agreement between the employer and the nurse; the relationship is mediated by the broker. Also, employees are not always protected by labour laws (Olojede and Rispel 2015: 2).

Feeling the pressure to help her daughter as soon as she could, she planned to do night shifts for at least six months on completion of her training. The pay was good, she explained, and it would allow her to 'moonlight' alongside another job. ${ }^{22}$ Her perception that moonlighting was highly lucrative was supported by accounts in the media. For instance, one report highlighted that nurses could earn considerably more in eight twelve-hour shifts moonlighting through agencies than in one month's work as a permanent employee in the public sector (Green 2005). For Mbali, the financial gains of casual employment were more appealing than the formal route to professionalization for now.

To earn enough money to meet daily expenditures, Mbali travelled regularly by bus to a large clothing warehouse run by an Indian family situated in the north of the city, over an hour's journey from her home. Here she would purchase clothes for door-to-door sale in Umlazi. When I accompanied her on one occasion, we meandered up and down the numerous aisles, perusing the neatly aligned racks of clothes. She picked out items for some of her regular customers whose tastes she knew well or who had issued her with specific requests. Her knowledge revealed the considerable effort expended on an activity that was both timeconsuming and fairly unprofitable. Yet it allowed her the flexibility to focus on her studies.

Mbali's probable career trajectory in the medium term involved a combination of formal and casual nurse employment in order to maximize her income with the key goal of supporting her children's education. Combining jobs in this way has become common in the context of wider national shifts. From the late 1990s onwards, the government implemented a programme of fiscal constraint in the health sector, 'establishing cost-containment as the de facto driver of everyday practice in the health system' (Schneider et al. 2007: 297). In nursing, fiscal austerity has led to stagnating wages and the freezing of posts, producing problems of poor retention and a shift towards casualization. Unable to fill posts or to afford 
permanent positions, many hospitals meet short-term demands by recruiting via agencies or paying existing staff to work overtime, with potentially detrimental effects on healthcare delivery (Rispel and Blaauw 2015; Rispel et al. 2014a). A large cross-sectional survey reveals the scale of casualization in nursing, showing that as many as 70 per cent of nurses combine their formal jobs with moonlighting, overtime and agency work. Nearly one in five nurses reported having done all three during the year prior to the study (Rispel et al. 2014b: 3). While pecuniary incentives were not the only reason for nurses to seek casual employment in addition to, or instead of, formal work, the study identifies them as the key factor.

Although able to afford a training course at a relatively prestigious college, Mbali's circumstances were a far cry from the middle-class life often associated with nurses in South Africa. As others have shown, long-term strategies of intergenerational social mobility are frequently prioritized over short-term expenditure, with frugality a necessary feature of middle-class strategizing (James 2015). Mbali's professionalization in formal-sector employment will likely be placed on hold while she focuses on her children's futures. Casual work also helped to mitigate unexpected costs. For instance, Mbali's situation became more strained when she was unexpectedly burdened with the care of another child following the death of her sister and sister's partner. The scale of the HIV/AIDS epidemic in South Africa has meant that such events are sadly all too common. Such factors intervened to create particular pressures and vulnerabilities at home. As Deborah Durham shows, aspirational identities entail 'a necessary entanglement of individual success with social mutualities' in ways that make one impossible without the other (Durham 2020). Should she achieve professional status as a nurse, these 'social mutualities', networks of mutual reciprocation and help between family and friends, will likely deepen. Conditions of austerity in the health sector combine with strained circumstances at home to produce ambivalence about the prospects of professional advancement.

This example, together with that of Mr Dlamini in the previous section, illustrates the ways in which public-sector employees at different career stages combine their formal job with other activities, either within nursing or beyond. However, differing levels of financial security mean that the incentives and opportunities for doing so vary. In the case of Mbali, casual employment and informal retail allowed her to make ends meet and to plan for her children's careers - even while potentially delaying her own. Aspiration and uncertainty about the 
future combined to influence particular decisions. The pursuit of a middle-class life was forged alongside processes intended to mitigate vulnerabilities or meet short-term financial needs. In Mr Dlamini's case, the strategy of combining a nursing salary with agriculture was a means of accumulation and of consolidating middle-class status. It also offered a way of staking 'independence', creating an experience of autonomy at a distance from nepotistic state practices. In both cases, wider forces of state intervention, economic policies and workplace pressures dovetailed with personal circumstances to produce middle-class strategies. Moreover, in both cases, reliance on government employment was necessary but problematic, reflecting ambivalence about the position of the aspiring middle classes vis-àvis the state.

\section{$<$ A $>$ Conclusion: professionalism, ambivalence and the precarity of middle-class belonging}

In Leo Kuper's analysis, feelings of ambivalence were common among the black middle classes, who struggled to reconcile the desire for professional advancement with the experience of racial discrimination in the workplace and, in some cases, the ethical dilemmas created by their position as tools of the apartheid state. By focusing an ethnographic lens, as Kuper did, on work itself and the intersections between work and home life, there is scope for reconsidering how middle-class experience in contemporary South Africa may be fraught or ambiguous. Despite the different prospects faced by the black middle classes in the postapartheid context - with a government seeking actively to support rather than to restrict social mobility - they nonetheless share with those described by Kuper an uneasy reliance on the state.

The middle classes harbour contradictory, ambivalent feelings because of the opposing forces acting on them. These arise partly from the continuing echoes of history. Professionalism itself is an ambivalent category in South Africa, tied closely to the apartheid project of separate development. Tensions are also created by contemporary experiences of denationalization and re-nationalization, deeply in tension with one another (Hart 2014). As the ANC's electoral support grows weaker, its stake in protecting professional interests is high. In debates about the proposed NHI system, visions of the public good are fused with nationalist discourses, forging the way for new alliances between the government-employed, aspiring middle classes and the ANC, and highlighting the significance of 're-nationalizing' forces, in Hart's terms. NHI represents the possibility of rejuvenating moral purpose among 
health workers in a way that may strengthen allegiance to the ANC. Yet experiences of work are strained, as fiscal austerity creates new hierarchies around formal and casualized labour. The need for a unified and expanding, skilled workforce, essential for the viability of NHI (Rispel 2018; Smith et al. 2018), is undermined by these deepening divisions.

Middle-class trajectories are caught within these oscillating tendencies, implying a more ambiguous relationship between the middle classes and the ANC than is suggested by generalizations of either a middle-class withdrawal from electoral politics or a monolithic state 'capture'. Moreover, narratives that emphasize the rise of the middle classes risk overlooking the growing precarity faced by its members and the feelings of ambivalence that pervade many aspects of life, from professional commitments to political allegiance. In a work context characterized by multiple, intersecting values and constraints, there are ideological, institutional and financial impediments to professional advancement in South Africa's public sector. This creates ambivalence among the aspiring middle classes about their attitudes to the ANC and their prospects within the current status quo. They follow strategies that suggest a tussle between dependence on and independence from the state and the party structures embedded in it. This has implications for understanding arguments about democratic renewal. Rather than operating in a civil society space removed from ANC politics, debates about the public good and the meanings of citizenship take place within it especially inside the ANC-governed institutions tasked with delivering democratic promises.

Class tensions within occupations are overlooked by narratives that focus exclusively on the 'increase' or 'growth' of the middle classes. Such an emphasis risks implying a straightforwardly linear process, seemingly echoing continent-wide claims of 'Africa rising' . Moving beyond reliance on voting behaviour or surveys, ethnographic analysis reveals that the post-apartheid making of the middle classes is not linear but occurs through struggle and ambiguity.

\section{$<$ ACK $>$ Acknowledgements}

I would like to thank the Economic and Social Research Council for funding part of this research. I am grateful to colleagues who attended the SOAS Anthropology Departmental Seminar for a stimulating discussion and useful suggestions, and to the two anonymous reviewers for the helpful feedback and encouragement.

\section{$<$ A $>$ References}


Barchiesi, F. (2011) Precarious Liberation: workers, the state, and contested social citizenship in postapartheid South Africa. Albany NY and Scottsville, South Africa: State University of New York Press.

Bear, L. (2015) Navigating Austerity: currents of debt along a South Asian river. Stanford CA: Stanford University Press. $<$ AQ1 $>$

Beinart, W. (2012) 'Beyond "homelands": some ideas about the history of African rural areas in South Africa', South African Historical Journal 64 (1): 5-21.

Berry, S. (1985) Fathers Work for their Sons: accumulation, mobility, and class formation in an extended Yorùbá community. Berkeley CA and London: University of California Press.

Bundy, C. (1988) The Rise and Fall of the South African Peasantry. London: James Currey.

Burns, C. (1998) "“A man is a clumsy thing who does not know how to handle a sick person": aspects of the history of masculinity and race in the shaping of male nursing in South Africa, 1900-1950', Journal of Southern African Studies 24 (4): 695-717.

Chipkin, I. and S. Meny-Gibert (2012) 'Why the past matters: studying public administration in South Africa', Journal of Public Administration 47 (1): 102-12.

Cohen, A. (1981) The Politics of Elite Culture: explorations in the dramaturgy of power in a modern African society. Berkeley CA and London: University of California Press.

Durham, D. (2020) 'Morality in the middle: choosing cars or houses in Botswana', Africa 90 (2): $\mathrm{xx}-\mathrm{xx}$.

Everatt, D. (2013) 'The South African middle class' in A. Bernstein (ed.), Rising Middle Classes in India, Brazil and South Africa: what is happening and what are the implications? Johannesburg: Centre for Development and Enterprise $<$ https://www.africaportal.org/publications/rising-middle-classes-in-india-brazil-and-southafrica-what-is-happening-and-what-are-the-implications>, accessed 6 March 2018.

Everatt, D. (2014) 'Gauteng and the arrival of uncertainty', Journal of the Helen Suzman Foundation 74: 10-18. 
Fernandes, L. (2006) India's New Middle Class: democratic politics in an era of economic reform. Minneapolis MN: University of Minnesota Press.

Fumanti, M. (2003) 'Youth, elites and distinction in a northern Namibian town'. PhD thesis, University of Manchester.

Fumanti, M. (2006) 'Nation building and the battle for consciousness', Social Analysis 50 (3): 84-108.

Gibbs, T. (2020) 'Apartheid South Africa's segregated legal field: black lawyers and the Bantustans', Africa 90 (1): 1-25.

Green, J. (2005) ‘Moonlighting nurses costing Gauteng millions', IOL, 22 August $<$ https://www.iol.co.za/news/south-africa/moonlighting-nurses-costing-gauteng-millions251358>, accessed 27 March 2018.

Harries, P. (1994) Work, Culture, and Identity: migrant laborers in Mozambique and South Africa, c.1860-1910. London: James Currey.

Hart, G. (2014) Rethinking the South African Crisis: nationalism, populism, hegemony. Athens GA and London: University of Georgia Press.

Heiman, R., C. Freeman and M. Liechty (eds) (2012) The Global Middle Classes: theorizing through ethnography. Santa Fe NM: School for Advanced Research Press.

Hull, E. (2009) 'Status, morality and the politics of transformation: an ethnographic account of nurses in KwaZulu-Natal, South Africa'. PhD thesis, London School of Economics and Political Science.

Hull, E. (2017) Contingent Citizens: professional aspiration in a South African hospital. London: Bloomsbury Academic.

Hunter, M. (2010) Love in the Time of AIDS: inequality, gender, and rights in South Africa. Bloomington IN: Indiana University Press.

Hunter, M. (2017) 'Parental choice without parents: families, education and class in a South African township', Compare: A Journal of Comparative and International Education 47 (1): $2-16$. 
Hyslop, J. (2005) 'Political corruption: before and after apartheid', Journal of Southern African Studies 31 (4): 773-89.

Jacobson, D. (1973) Itinerant Townsmen: friendship and social order in urban Uganda. Menlo Park CA: Cummings.

James, D. (2015) Money from Nothing: indebtedness and aspiration in South Africa. Stanford CA: Stanford University Press.

Kitching, G. (1980) Class and Economic Change in Kenya: the making of an African petite bourgeoisie, 1905-1970. New Haven CT: Yale University Press.

Konings, P. and J. Ravell (1986) The State and Rural Class Formation in Ghana: a comparative analysis. London: Routledge.

Kuper, L. (1965) An African Bourgeoisie: race, class and politics in South Africa. New Haven CT and London: Yale University Press.

Lentz, C. (2016) 'African middle classes: lessons from transnational studies and a research agenda' in H. Melber (ed.), The Rise of Africa's Middle Class: myths, realities and critical engagements. London: Zed Books.

Lentz, C. (2020) 'Doing being middle class in the global South: comparative perspectives and conceptual challenges', Africa 90 (2): xx-xx.

Lipset, S. M. (1959) 'Some social requisites of democracy: economic development and political legitimacy', American Political Science Review 53 (1): 69-105.

Lodge, T. (2014) 'Neo-patrimonial politics in the ANC', African Affairs 113 (450): 1-23.

Mabandla, N. (2015) 'Rethinking Bundy: land and the black middle class - accumulation beyond the peasantry', Development Southern Africa 32 (1): 76-89.

Mafika. (2013) 'South Africa moves to revitalise nursing', SA Fast Facts, 12 March $<$ https://www.brandsouthafrica.com/south-africa-fast-facts/health-facts/nursing-120313>, accessed 14 March 2018.

Marais, H. (2011) South Africa Pushed to the Limit: the political economy of change. London: Zed Books. 
Marks, S. (1994) Divided Sisterhood: race, class and gender in the South African nursing profession. Johannesburg: Witwatersrand University Press.

Marks, S. (2002) “"We were men nursing men": male nursing on the mines in twentiethcentury South Africa' in W. Woodward, P. Hayes and G. Minkley (eds), Deep hiStories: gender and colonialism in Southern Africa. New York NY: Rodopi.

Mattes, R. (2015) 'South Africa's emerging black middle class: a harbinger of political change?', Journal of International Development 27 (5): 665-92.

Moodie, T. D. (1994) Going for Gold: men, mines, and migration. Berkeley CA and London: University of California Press.

Moore, B. (1966) Social Origins of Dictatorship and Democracy: lord and peasant in the making of the modern world. Boston MA: Beacon Press.

Musyoka, J. (2018) 'State capture fails the black middle class', Mail and Guardian, 22 June $<$ https://mg.co.za/article/2017-06-22-00-state-capture-fails-the-black-middle-class?>, accessed 27 March 2018.

Naidoo, S. (2012) 'The South African National Health Insurance: a revolution in health-care delivery!', Journal of Public Health 34 (1): 149-50.

Netshitenzhe, J. (2014) “"Radical” change is our collective responsibility', Mail and Guardian, 26 June < https://mg.co.za/article/2014-06-26-radical-change-is-our-collectiveresponsibility>, accessed 27 March 2018.

Ngoma, A. L. (2016) 'South Africa's black middle class professionals' in H. Melber (ed.), The Rise of Africa's Middle Class: myths, realities and critical engagements. London: Zed Books.

Olivier de Sardan, J. (2014) 'The delivery state in Africa: interface bureaucrats, professional cultures and the bureaucratic mode of governance' in T. Bierschenk and J. Olivier de Sardan (eds), States at Work: dynamics of African bureaucracies. Leiden: Brill.

Olojede, O. I. and L. C. Rispel (2015) 'Exploring the characteristics of nursing agencies in South Africa', Global Health Action 8: 27878. 
Pfeiffer, J. (2019) 'Austerity in Africa: audit cultures and the weakening of public sector health systems', Focaal 2019 (83): 51-61.<AQ2>

Phadi, M. and C. Ceruti. (2011) 'Multiple meanings of the middle class in Soweto, South Africa', African Sociological Review / Revue Africaine de Sociologie 15 (1): 87-107.

Powers, T. (2019) 'Echoes of austerity: policy, temporality, and public health in South Africa', Focaal 2019 (83): 13-24.

Powers, T. and T. Rakopoulos (2019) 'The anthropology of austerity: an introduction', Focaal 2019 (83): 1-12.

Rispel, L. C. (2018) 'South Africa's universal health care plan falls short of fixing an ailing system', The Conversation, 28 June $<$ https://theconversation.com/south-africas-universalhealth-care-plan-falls-short-of-fixing-an-ailing-system-99028>, accessed 16 December 2019.

Rispel, L. C. and D. Blaauw (2015) 'The health system consequences of agency nursing and moonlighting in South Africa', Global Health Action 8: 26683.

Rispel, L. C., T. Chirwa and D. Blaauw (2014a) 'Does moonlighting influence South African nurses' intention to leave their primary jobs?', Global Health Action 7: 25754.

Rispel, L. C., D. Blaauw, T. Chirwa and K. de Wet (2014b) 'Factors influencing agency nursing and moonlighting among nurses in South Africa', Global Health Action 7: 23585.

Saul, J. S. and P. Bond (2014) South Africa: the present as history. Woodbridge: James Currey.

Schielke, S. (2015) Egypt in the Future Tense: hope, frustration, and ambivalence before and after 2011. Bloomington IN: Indiana University Press.

Schlemmer, L. (2005) 'Lost in transformation? South Africa's emerging middle class'. CDE Focus 8. Johannesburg: Centre for Development and Enterprise (CDE)

$<$ https://www.africaportal.org/publications/lost-in-transformation-south-africas-emergingmiddle-class $>$, accessed 21 February 2018. 
Schneider, H., P. Barron and S. Fonn (2007) 'The promise and the practice of transformation in South Africa's health system' in S. Buhlungu, J. Daniel, R. Southall and J. Lutchman (eds), State of the Nation: South Africa 2007. Cape Town: HSRC Press.

Smith, A., S. Ranchod, D. Strugnell and J. Wishnia (2018) 'Human resources for health planning and National Health Insurance: the urgency and the opportunity' in L. C. Rispel and A. Padarath (eds), South African Health Review 2018. Durban: Health Systems Trust.

Southall, R. (2016) The New Black Middle Class in South Africa. Woodbridge: James Currey.

Spronk, R. (2012) Ambiguous Pleasures: sexuality and middle-class self-perceptions in Nairobi. Oxford and New York NY: Berghahn Books.

Sumich, J. (2018) The Middle Class in Mozambique: the state and the politics of transformation in Southern Africa. New York NY: Cambridge University Press.

Visagie, J. and D. Posel (2013) 'A reconsideration of what and who is middle class in South Africa', Development Southern Africa 30 (2): 149-67.

von Holdt, K. (2010) 'The South African post-apartheid bureaucracy: inner workings, contradictory rationales and the developmental state' in O. Edigheji (ed.), Constructing a Democratic Developmental State in South Africa: potential and challenges. Cape Town: HSRC Press. 
${ }^{1}$ See Lentz (2020) for a summary of these discussions.

${ }^{2}$ Anthropologists are increasingly focusing on austerity beyond European contexts (Bear 2015; Pfeiffer 2019; Powers 2019). Powers and Rakopoulos note that 'austerity might be a “European" term but it is not a European-only condition' (Powers and Rakopoulos 2019: 2).

${ }^{3}$ It has become normal practice in media and academic discussion to use the term 'black middle class' to refer specifically to the 'black African middle class', which is how I use the term here. Earlier literature uses the term 'African' instead of 'black', and I adopt this terminology when referring to this literature.

4 The 'homelands', also known as Bantustans, were territories set aside by the apartheid government for the purpose of creating ethnically homogeneous, independent states for South Africa's black ethnic groups. Ten were created altogether. They were subsequently dismantled following the democratic elections in 1994.

${ }^{5}$ Aspirations to become middle class are themselves an important subject to study, given the way in which middle-class belonging becomes 'a powerful, life-altering goal for many of those poised on the margins' (Heiman et al. 2012: 19).

${ }^{6}$ The terms 'elite' and 'middle class' have sometimes been used interchangeably in scholarship on Africa, although they derive from different scholarly traditions (Lentz 2016). ${ }^{7}$ In India, the retreat of the middle classes from formal electoral politics can accompany a resurgence of middle-class politics in other forms, for instance through support for liberalization or Hindu nationalism (Fernandes 2006: 174).

${ }^{8}$ Prominent examples include works by Colin Bundy (1988), Patrick Harries (1994) and T. Dunbar Moodie (1994).

${ }^{9}$ This has consequences not only for understanding class formation. Lack of attention to occupations, especially professional and semi-professional workplaces, has left an absence of critical analysis of public administration in the post-apartheid period such that, by 2012 , Chipkin and Meny-Gibert remarked on the overwhelming paucity of critical scholarship on public-sector institutions in South Africa (Chipkin and Meny-Gibert 2012).

10 The names of my interlocutors are pseudonyms.

11 The 'homeland' of KwaZulu was officially formed in 1970. It was granted internal selfgovernment in 1977.

${ }^{12}$ While for most of the twentieth century no more than 5 per cent of nurses have been men, up until the 1970s mine hospitals were serviced almost entirely by men (Marks 2002: 180). 
For an account of male nursing in South Africa in the first half of the twentieth century, see Burns (1998).

${ }^{13}$ Few of the male orderlies continued in their career to become fully registered nurses and they were ultimately replaced (though not entirely) by female nurses. The class status of male orderlies was part of the reason why the job became less appealing to men: 'They had neither the education nor the class background to provide a model for the sons of professional nurses' (Marks 2002: 198). After the 1980s, there was a small increase in the numbers of professional black male nurses, which Marks attributes to 'the dramatic increase in male unemployment in other sectors of the economy' (ibid.: 181). This supports the argument that men are attracted to nursing due to limited options.

${ }^{14}$ I explain this issue at greater length in Contingent Citizens, especially Chapter 5 (Hull 2017).

15 'Power elites' use covert, social networks informally to close the boundaries of class access (Cohen 1981).

16 'Matron' is a term used for nurses in senior managerial positions.

${ }^{17}$ This is supported by Ngoma's observation that the black professionals in her study avoided party politics because of a "perceived lack of tolerance for "dissent" or opposing views within the ANC branches' (Ngoma 2016: 181).

${ }^{18}$ Visagie and Posel identify the 'affluent middle class' - i.e. individuals with a middle-class lifestyle - as those earning between 1,400 and 10,000 rand per month (2013: 158).

${ }^{19}$ In a statement released by South Africa's largest trade union group, the Congress of South African Trade Unions (COSATU), NHI was characterized as a 'watershed moment', meeting the objectives of the 1943 Africans' Claims and the 1955 Freedom Charter - two seminal documents setting out the political demands and core principles of the ANC and its allies during the struggle for racial liberation. COSATU's statement claimed that it will 'help define our second radical phase of our national democratic revolution' (see $<$ http://www.cosatu.org.za/show.php?ID=11229>, accessed 5 February 2018).

Marais argues that while the national democratic revolution lacks usefulness conceptually for understanding South African political economy, it works as an ideological tool for 'affirming the pre-eminence of the ANC' and 'marshal[ling] consent for a hegemonic work-in-progress' (Marais 2011: 400).

${ }^{20}$ Most township houses built in the apartheid era consisted of a living room, a kitchen, two bedrooms and an inside toilet. They were known as 'matchbox' houses and contained a living space of 51.2 square metres in total (Hunter 2010: 67). 
${ }^{21}$ Agency work is a form of casual employment via a temporary employment service provider (the nursing agency) that contracts the nurse to a public or private health facility.

${ }^{22}$ Moonlighting is typically understood as having at least one extra job, in addition to a fulltime primary job. 